\title{
NOMA as the Cure for Conflict Between Science and Religion: Reply to Ludwik Kowalski's Commentary on the NOMA Principle
}

There are two basic themes in Ludwik Kowalski's commentary on the NOMA principle. The main one is the socio-political problem: how theists and atheists can live together peacefully. The second issue is the resolution of this problem. Kowalski finds this resolution in the NOMA principle introduced by Stephen Jay Gould, and it is this second issue on which I will focus. I will indicate that: 1) there is an imprecision in Kowalski's presentation of the NOMA principle; 2) the NOMA principle is not a valid way of presenting theistic religions; 3) the argumentation adopted by Kowalski is inconsistent, due to inconsistency in the NOMA principle itself.

\section{(1) Imprecision in Kowalski's presentation of the NOMA principle}

According to Kowalski, Gould's idea of non-overlapping magisteria refers to the methodological aspect of science and religion: "[...] the phrase «nonoverlapping》 should be interpreted as differences in methods of investigation of our world". ${ }^{1}$ This is imprecise, as Gould stated that the lack of overlap refers to

\footnotetext{
${ }^{1}$ Ludwik Kowalski, "Confrontations Between Theists and Atheists", Filozoficzne Aspekty Genezy 2014, vol. 11, p. 23 [23-28], http://www.nauka-a-religia.uz.zgora.pl/images/FAG/2014.t. 11/art.02.pdf (05.04.2015).
} 
the object of the scientific and religious inquiry, not just to the methodology: "The lack of conflict between science and religion arises from a lack of overlap between their respective domains of professional expertise - science in the empirical constitution of the universe, and religion in the search for proper ethical values and the spiritual meaning of our lives". ${ }^{2}$ Hence, science deals with the empirical constitution of the universe, while religion is about values, the meaning of our lives etc. It may be true that the differences in these subjects entail methodological differences in the way they are studied. However, surely it is the merits of the scientific and religious claims which, according to Gould, are supposed to be separated. This is stated also in the following quotation by Gould, in which he expresses his resolution of supposed conflict between science and religion. According to Gould:

No such conflict should exist because each subject has a legitimate magisterium, or domain of teaching authority - and these magisteria do not overlap (the principle that I would like to designate as NOMA, or "nonoverlapping magisteria"). The net of science covers the empirical universe: what is it made of (fact) and why does it work this way (theory). The net of religion extends over questions of moral meaning and value. ${ }^{3}$

Hence, according to Gould, the domain of teaching authority occupied by scientific "research" is not held common with that of religion. It is also important to note that it is possible to use different kinds of methodology in investigating the same object. For the relationship between science and religion, it is important to distinguish whether or not they share a common object, or just common methodology.

\section{(2) The NOMA principle is not a valid way of presenting theistic religions}

An essential element of theism is a statement regarding God's influence in the world after its creation. In theistic religions this influence is often expressed

\footnotetext{
${ }^{2}$ Stephen Jay Gould, "Nonoverlapping Magisteria", Filozoficzne Aspekty Genezy 2014, vol. 11. p. 9 [7-21], http://www.nauka-a-religia.uz.zgora.pl/images/FAG/2014.t.11/art.01.pdf (05.04. 2015).

${ }^{3}$ Gould, "Nonoverlapping Magisteria...”, p. 12.
} 
by so-called miracles or divine interventions in the natural, empirical sphere. Miracles do not necessarily break the laws of nature. Their important characteristic is rather that they are empirically recognizable. The empirical character of these interventions is connected with their apologetic or faith-building function. Statements describing events in the empirical sphere are the element that distinguishes the theistic picture of the empirical sphere from the materialistic or the deistic ones. They also differentiate one religion from another. Mighty acts of God in the history of Israel are described in the Hebrew Bible as the source of religious motivation: "And when the Israelites saw the mighty hand of the Lord displayed against the Egyptians, the people feared the Lord and put their trust in him and in Moses his servant" (Ex. 14:31 NIV). Similarly, according to some Christians, the mission of Jesus was confirmed by a number of empirically recognizable miracles that he made. It is quite a common opinion in Christianity that "His miracles provided confirmation that the long-awaited day of the Lord had come with the activities of the divinely commissioned Messiah". ${ }^{4}$ In other theistic religions one finds different empirical statements describing divine action that make these religions unique among the rest. Hence, the empirical character of certain statements describing God's interventions in the empirical sphere is a crucial element of the Judeo-Christian theism. The religious perspective most consistent with NOMA is likely deism, which has been recognized as heterodoxy from the point of view of Christianity. ${ }^{5}$

Hence, empirical statements are an important part of theistic religions. According to Gould, "the net of science covers the empirical universe". However, this is true also of theistic religions: the net of religion also covers the empirical universe, the domain of facts and evidence. Exclusion of empirical statements on divine action from religion is rather an essential revision of theistic religions.

\footnotetext{
${ }^{4}$ Paul BarnetT, Messiah: Jesus - the Evidence of History, InterVarsity Press, Nottingham 2009, p. 92.

${ }^{5}$ See Kazimierz JodKowski, "NOMA, cudy i filtr eksplanacyjny" ("NOMA, Miracles, and Explanatory Filter"), Roczniki Filozoficzne 2005, vol. 53, no. 2, p. 91 [83-103]; Kazimierz JoDKowsKI, "Epistemiczne układy odniesienia i «warunek Jodkowskiego»" ("Epistemic Frameworks and the «Jodkowski's Condition»"), in: Anna LatawiEC and Grzegorz BugajaK (eds.), Filozoficzne i naukowo-przyrodnicze elementy obrazu świata 7, Wydawnictwo Uniwersytetu Kardynała Stefana Wyszyńskiego, Warszawa 2008, p. 115 [108-123].
} 
Yet, Kowalski invokes the philosophy of Spinoza as an example of a belief in God that is free from miracles: "But one can believe in God without believing in miracles, as Spinoza did. His God was nature itself, not an entity outside of nature. The idea of an external God was formulated by humans. It evolved and is still evolving - naturally". ${ }^{6}$ First, Spinoza's type of religion is not theism. Second, the concept that the idea of a transcendent God was invented by humans could not be farther from the view of theistic religions. In theistic religions like Judaism, Christianity or Islam, there is an assumption that divine revelation plays an important role in the recognition of God's existence and God's relation to the world.

Hence, to "believe in God without believing in miracles, as Spinoza did", is not theism. It is deism or pantheism (as in the case of Spinoza). Yet, the title of Kowalski's commentary refers to the relation of theism (not deism or pantheism) vs. atheism.

\section{(3) The problem of consistency}

According to Kowalski, the essential difference between scientific methodology and a religious method of argumentation is that the first one is based solely on empirical evidence, while the other is based on intuition and consistency with holy books: "Scientific theories are accepted or rejected solely on the basis of laboratory work and observations of our material world"; 7 " [...] theological theories, on the other hand, are usually accepted or rejected on the basis of intuition, and on the basis of logical consistency with holy books. The first approach is effective in investigations of material phenomena while the second is effective in investigations of spiritual phenomena". ${ }^{8}$ Kowalski indicates also the division of cognitive competences of science and religion. This is compatible with the division of these competences proposed by Gould (the only difference is that Gould wrote about moral values and the meaning of existence, while Kowalski uses the category of spiritual phenomena).

\footnotetext{
${ }^{6}$ Kowalski, „Confrontations...”, p. 24.

${ }^{7}$ Kowalski, „Confrontations...”, p. 24.

${ }^{8}$ Kowalski, “Confrontations...”, p. 27.
} 
However, this approach leads to an interesting problem of the consistency of this position with decisions on truth value of religious factual statements. We find this problem in Kowalski's presentation of Modern Reform Judaism: "Modern Reform Judaism is rooted in the nineteenth-century question - «is the Torah history or legend?» The German Rabbi Abraham Geiger asked: «How much longer can we continue this deceit $[\ldots]$ presenting stories from the Bible as if they were actual historical happenings?»". ${ }^{9}$ Yet, how can one know whether this or that Biblical story is a deceit? When we argue that some happenings described in the Bible did not take place - as science tells us that it was impossible, improbable or just false - then we decide what is true in the domain of religion by reference to scientific methodology based on scientific evidence and scientific premises. If so, then theological theories seem to be accepted or rejected on basis of scientific stipulations. This is not consistent with the approach of nonoverlapping magisteria, which assumes that domains of science and religion are separate. By accepting NOMA we make decisions about the relative truth values of religious statements, and doing so is inconsistent with NOMA itself.

\section{Conclusion}

The proposed "cure" for the conflict between science and theistic religion (and atheism vs. theism) occurs to be the elimination of essential elements of theistic religions. The postulate of a "miracle-free" theism is similar to postulates of e.g. "kosher-free" Judaism or "Ramadan-free" Islam with regard to the degree of modification of the real theistic religions. In fact, it leads to the elimination of these religions themselves. Hence, the cure for the "Confrontations Between Theists and Atheists" mentioned in the title of the Kowalski's commentary is the elimination of theism. One important weakness of Kowalski's proposal and of the application of the NOMA principle in general is the self-contradictoriness of this position: when we decide on the truth value of this or that factual religious statement by reference to science, then we deny the essence of the NOMA principle itself.

Piotr Bylica

\footnotetext{
${ }^{9}$ Kowalski, “Confrontations...”, p. 25.
} 


\section{NOMA as the Cure for Conflict Between Science and Religion: Reply to Ludwik Kowalski's Commentary on the NOMA Principle}

\section{Summary}

In my response to Kowalski's commentary I indicate that: 1) there is an imprecision in Kowalski's presentation of the NOMA principle; 2) the NOMA principle is not a valid way of presenting theistic religions; 3) the argumentation adopted by Kowalski is inconsistent, due to inconsistency in the NOMA principle itself. The Kowalski's cure for the "Confrontations Between Theists and Atheists" mentioned in the title of the Kowalski's commentary is the postulate of a "miracle-free" theism, which means the elimination of theism. Another important weakness of Kowalski's proposal and of the application of the NOMA principle in general is the self-contradictoriness of this position: when we decide on the truth value of this or that factual religious statement by reference to science, then we deny the essence of the NOMA principle itself.

Keywords: NOMA, Christian theism, science and religion, Stephen Jay Gould, deism, atheism, miracles. 